\title{
Ornamental fishing in the region of Barcelos, Amazonas: socioeconomic description and scenario of activity in the view of "piabeiros"
}

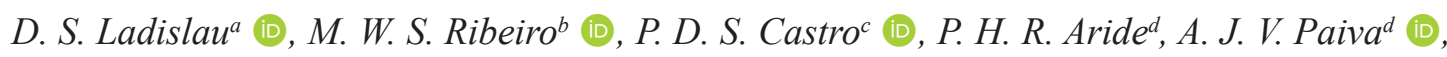 \\ M. F. Polese e (D), A. B. Souza (D), L. A. Bassule (D), H. D. Lavandere (D) and A. T. Oliveira ${ }^{d *}$ (D) \\ aPrograma de Pós-graduação em Recursos Pesqueiros e Engenharia de Pesca - PREP, Universidade Estadual do Oeste do \\ Paraná - UNIOESTE, Rua da Faculdade, 645, Jardim La salle, CEP 85903-000, Toledo, PR, Brasil \\ bPrograma de Pós-graduação em Aquicultura, Instituto Nacional de Pesquisas da Amazônia - INPA, Universidade Nilton \\ Lins, Av. Professor Nilton Lins, 3260, Parque das Laranjeiras, CEP 69058-040, Manaus, AM, Brasil \\ 'Universidade Federal do Amazonas - UFAM, Av. General Rodrigo Octávio Jordão Ramos, 6200, Coroado I, \\ CEP 69077-000, Manaus, AM, Brasil \\ Instituto Federal de Educação, Ciência e Tecnologia do Amazonas - IFAM, Campus Manaus Centro - CMC, Av. Sete de \\ Setembro, 1975, CEP 69020-120, Manaus, AM, Brasil \\ 'Instituto Federal de Educação, Ciência e Tecnologia do Espírito Santo - IFES, Campus Piúma, R. Augusto Costa de \\ Oliveira, 660, CEP 29285-000, Piúma, ES, Brasil \\ *e-mail: adriano.oliveira@ifam.edu.br
}

Received: October 27, 2018 - Accepted: March 15, 2019 - Distributed: 31 August, 2020

(With 9 figures)

\begin{abstract}
The Negro river basin is considered the largest area of extractive of ornamental fish in Brazil. This area has fundamental importance for the populations from the Amazon. The present study aimed to describe socioeconomic profile of ornamental fishermen known as "piabeiros" in the Municipality of Barcelos, as well as the ornamental fishery, fisheries area, target species, environments, fishing techniques, equipment, capture techniques and main difficulties faced by the current activity. This study was carried out in municipality of Barcelos, through semi - structured interviews, with artisanal ornamental fishermen $(\mathrm{N}=89)$. The main families of ornamental fish caught and traded were: Characidae, Lebiasinidae, Gasteropelecidae, Cichilidae, Anostomidae, Loricaridae, Potamotrygonidae and Gymnotidae. The main catchment areas were igarapés, lakes, flooded fields, beaches, river banks and igapó forest. Rapiché was the most used equipment in the fisheries both by the fishermen of the urban areas (43.81\%) and rural (41.89\%). Most of the fishermen are associated with the colony of fishermen of Barcelos (Z33). The data showed that the dynamics of ornamental fishing have changed in a short time and directly affected fishermen, in addition to the low age renewal with the participation of younger fishermen, threatening the transmission of ecological knowledge to future generations. As a result, the increase of the problems related to the productive chain and absence of public power to the activity, since ornamental fishing has already been treated as one of the main economic activities more important for the local communities and for the State of Amazonas.
\end{abstract}

Keywords: socioeconomics, artisanal fishermen, ornamental fishing, Barcelos, Amazon.

\section{A pesca ornamental na região de Barcelos, Amazonas: descrição socieconômica e cenário da atividade na visão dos piabeiros}

\begin{abstract}
Resumo
A bacia do rio Negro é considerada a maior área de extrativismo de peixes ornamentais do Brasil. Esta área possui importância fundamental para as populações da Amazônia. O presente estudo objetivou descrever o perfil socioeconômico de pescadores conhecidos como "piabeiros" no município de Barcelos, bem como a pesca ornamental, área de pesca, espécies-alvo, ambientes, técnicas de pesca, equipamentos, técnicas de captura e dificuldades enfrentadas nesta atividade. $\mathrm{O}$ estudo foi realizado por meio de entrevistas semi - estruturadas, com pescadores artesanais ornamentais $(\mathrm{N}=89)$. Os dados mostram que as famílias de peixes ornamentais capturados e comercializados foram: Characidae, Lebiasinidae, Gasteropelecidae, Cichilidae, Anostomidae, Loricaridae, Potamotrygonidae e Gymnotidae. As áreas de captura descritas foram igarapés, lagos, alagados, praias, margens de rios e floresta de igapó. O Rapiché foi o equipamento mais utilizado nas pescarias tanto pelos pescadores das áreas urbanas $(43,81 \%)$ como rurais $(41,89 \%)$. A maioria dos pescadores está associada à colônia de pescadores de Barcelos (Z33). Os dados coletados mostraram que
\end{abstract}


a dinâmica da pesca ornamental mudou em pouco tempo e afetou diretamente os pescadores. Além da baixa taxa de renovação, com a participação de pescadores mais jovens, ameaçando a transmissão de conhecimento ecológico para as gerações futuras. Como resultado, notamos o aumento dos problemas relacionados à cadeia produtiva e a ausência de poder público na atividade. A pesca ornamental já foi tratada como uma das principais atividades econômicas para as comunidades locais e para o Estado do Amazonas.

Palavras-chave: socioeconomia, pescadores artesanais, pesca ornamental, Barcelos, Amazônia.

\section{Introduction}

In Brazilian Amazonian Area, the fishing activity involves 368 thousand fishermen approximately, and has a production of 166,477 tons of annual fish, moving US\$ 130 million, being the North area the main responsible for fishing production of continental waters in the year of 2009, where the states of Amazon (71,110 tons) and Pará $(42,083$ tons) they were the main producers in relation to the volume of capture of fish of the area on this year (Brasil, 2010). Thus, the Amazonian area is holder of the highest values of consumption per capita of fish with 380 to $600 \mathrm{~g} /$ day. The fish is the main source of proteins of the riverine populations (Lima et al., 2012).

In the Amazonian basin they can be found six fishing modalities, being these: subsistence, commercial multi specified, commercial mono specified, fishes in reservoirs, fishes sporting and the ornamental fishing (Freitas and Rivas, 2006). The commercial fishing and the one of subsistence is the ones that represent larger source of jobs generation and income in the fishing section in the area (Lima et al., 2012). Besides these, the ornamental fishing is described as fundamental importance for the local riverine populations, being this responsible one for the subsistence of the same ones in several areas of the Amazonian (Anjos et al., 2009), with prominence in Barcelos area (Medio River Negro) (Oliveira et al., 2016, 2017a, b).

The Amazonian basin is the main area of fishing extractivist of ornamental fish of Brazil, happening in the areas of Medio River Xingu, River Tapajós, River Purus, River Juruá, Medio River Solimões and Medio River Negro. The basin of Medio River Negro in the State of Amazonas is the area of larger representativeness of this activity of the country, exporting about 20 million fish/year generating for the economy of the state about of US\$ 3 million (Chao and Prang, 1997). The ornamental fishing practiced in this area used 10 thousand people approximately in Amazonas, being responsible for about $60.0 \%$ of the income of the municipal districts of Barcelos and Santa Isabel in Negro River, demonstrating to strong connection that those areas had with the international trade of ornamental fish at that time (Prang, 2001).

In the last decades the ornamental fishing practiced in the area of Medio Negro River has been suffering changes in socioeconomic scenery, influenced by the economic crisis of the last decade, besides linked problems the lack of organization of the local productive chain, of the high taxes of imposed on the exported products, of the reproduction in captivity of the main species as the cardinal Paracheirondon axelrodi and the neon tetra Paracheirondon innesi for countries importers as USA, Europe and Asia. Besides, the competition with the countries South American neighbors, like Colombia, Venezuela, Ecuador, Guyana and Peru, where the commercialization of the species that has sale for ornamental ends prohibited at the country, they are offered without any restriction type and for values below practiced them in the national market (Prang, 2001).

Such economical events consequently contributed in a direct and indirect way to reduction of the export volume of coming fish from the area of Medio Negro River, taking many piabeiros and craft fishermen of ornamental fish to abandon the activity, migrating for new economic activities close to the headquarters of the Municipal district of Barcelos, such as guides in the sporting fishing (Sobreiro, 2016; Ferreira et al., 2017).

In the field of ethnoichthyology, many works have been carried out in the last decade, adopting different themes, in order to describe the different ways of use and cognitive knowledge of local communities (ecology and classifications of organisms). The works with local ecological knowledge of artisanal ornamental fishermen developed in the Amazon region, more precisely in the basin of the middle Solimões river (Amazonas) and in the middle Xingu river (Pará) (Mendonça and Camargo, 2006; Souza and Mendonça, 2009; Carvalho-Júnior et al., 2009; Rossoni et al., 2014; Ramos et al., 2015) In addition, it is important to note that there is a high correlation between the number of ornamental species and the number of ornamental species studied, emphasizing the importance of including this knowledge in local fisheries management strategies.

It is well known that artisanal fishermen have detailed knowledge on ecological, behavioral and fish classification issues, and this knowledge is influenced and influenced by fishing practices (Begossi et al., 2016). This reality can be observed in the daily life of the artisanal fisherman in the Amazon region. Through the cognitive capital (empirical knowledge) acquired through years of experience in the activity (work practices), they are able to employ and choose the best technique, equipment and location (Witkoski et al., 2009; Batista and Lima, 2010).

In spite of the ornamental fishing to be an activity with more than half century of existence in the area of the basin of Medio Negro River, and of great economic and social importance for the riverine communities, it exists a lack of information related to the degree of socioeconomic contribution that this activity carries out on the community that depends on this as main sustenance source and income, being necessary the rising of information that describe the aspects social, ecological and economical of these activities in the area. 
The aim of this study was describes the socioeconomic profile of the fishermen of ornamental fish of the area of Medio Rio Negro, recognized popularly as "piabeiros" in the Municipal district of Barcelos, as well as the scenery of the ornamental fishing practiced locally, pointing the main flood plain times to fishing, main species, fishing atmospheres, equipment used and capture techniques.

\section{Material and Methods}

\subsection{Study area}

The present study was accomplished in the areas urban and rural of the Municipal district of Barcelos, State of Amazon (Figure 1). The city of Barcelos was the first capital of the state of Amazon in 1758, used as warehouse for slave expeditions and later for the vegetable (cycle of the eraser) extraction and installation of agricultural projects for the cultivation of coffee and tobacco (Machado, 2001).

The municipal district of Barcelos is considered the largest municipal district in territorial extension of the State of Amazonas with 112,450.76 km² located to 496 of distance of the capital Manaus, with thirst the right margin of Médio Rio Negro and possesses a population about 26,000 inhabitants (IBGE, 2017).

In this area it is located the Area of Mariuá Environmental Preservation, considered the largest fluvial archipelago of fresh water of the world, with about of 1,600 islands, besides the Jaú National Park and Araçá State Park (Inomata and Freitas, 2015).

\subsection{Data collection}

The data were obtained through interviews semi structured with application of questionnaires containing open and closed questions, with craft fishermen of ornamental fish known locally as "piabeiros" $(\mathrm{N}=89)$, in the period among January to April of 2016.
The accomplished questions were destined the obtaining of information on the socioeconomic (gender, age group, marital status, naturalness, monthly income, education and economical activities developed in the district) profile and aspect of the ornamental fishing practiced in the area (time, species, atmospheres, equipment's and capture techniques, association and problems in the execution of the activity). The average of the time of the interviews was of 30 minutes in individual ways, with the due presentation of the Free and Illustrious (TCI) Term of Consent to the interviewee and previous edition of "Plataforma Brasil" (N. 53847316.6.0000.5015), always with an accessible language to have owed understanding of the paper of the participation of the piabeiros in the respective study.

Was carried out a consultation to Fishing Cologne of Barcelos Z33 for determination of the number of fishermen in active state in the ornamental fishing in the Municipal district of Barcelos, where they were pointed 135 assets being 97 men and 38 women (2016).

The places of interviews were determinate with random in the urban area after the researcher's previous identification and the invitation to candidate the participation. For the rural area the determination happened in agreement with the representation level that the ornamental fishing had for to present community riverine, as informed for piabeiros-key in the headquarters of Barcelos.

The present study was accomplished in the urban and rural area of the Municipal district of Barcelos. Eleven communities were visited in the rural area, being these: Ponta da Terra, Santa Inês, Daracuá, Mulufú, Romão, Elesbão, Bacabal and Jaqueira (Table 1). The field study was accomplished in the month of January in the urban area and month of April in the rural area (2016), for half fluvial in an embarkation of medium load, tends exit of the headquarters of the Municipal district of Barcelos. The area is characterized as the tributaries of larger representativeness of the ornamental fishing in the area (Aracá and Demeni Rivers).

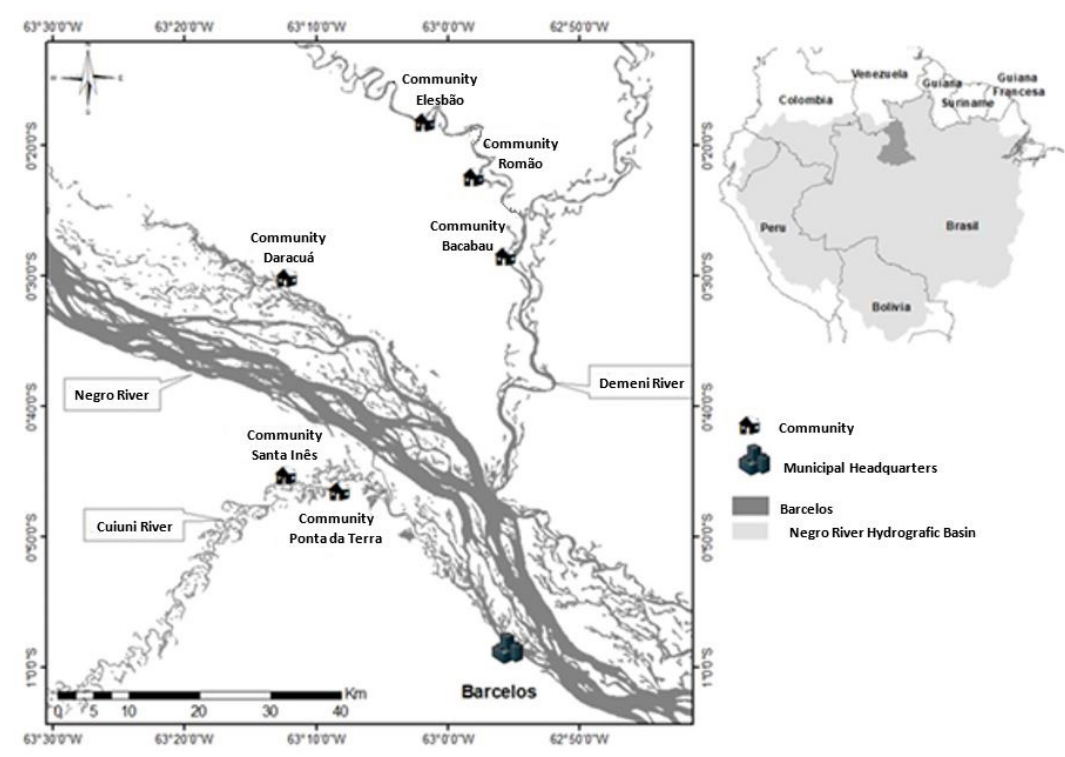

Figure 1. Municipality of Barcelos in the Medio River Negro basin, State of Amazonas. 
Table 1. Frequency of interviews in communities located in the Municipality of Barcelos, Amazonas, Brazil.

\begin{tabular}{clc}
\hline Order & \multicolumn{1}{c}{ Locations } & $\begin{array}{c}\text { Frequency } \\
(\mathbf{\%})\end{array}$ \\
\hline 1 & $\begin{array}{l}\text { Headquarters of the } \\
\text { municipality of Barcelos }\end{array}$ & 58.43 \\
2 & Community Ponta da Terra & 8.99 \\
3 & Community Santa Inês & 4.49 \\
4 & Community Daracuá & 8.99 \\
5 & Community Mulufú & 6.74 \\
6 & Community Romão & 3.37 \\
7 & Community Elesbão & 4.49 \\
8 & Community Bacabal & 2.25 \\
9 & Community Jaqueira & 2.25 \\
10 & Community Alalaó & - \\
11 & Community Maquí & - \\
\hline
\end{tabular}

\subsection{Analysis of data}

The obtained data were used for the construction of graphs and tables and presented through descriptive statistics with calculation of relative frequency.

\section{Results}

The frequency of interviewees in the communities was showed in Table 1, in which it presents the highest percentage of respondents in the urban area. The naturality of the interviewees from municipality of Barcelos was showed in Table 2, being the city of Barcelos the highest percentage recorded. The area covered by the study was the municipality of Barcelos, with the communities of Ponta da Terra, Santa Inês, Daracuá, Bacabal, Romão and Elesbão (Figure 1). The representation of genus was represented in Table 3, in which the majority of fishermen interviewed are male.

Table 2. Naturality of the interviewees in the urban and rural areas of the Municipality of Barcelos, Amazonas, Brazil.

\begin{tabular}{|c|c|c|c|c|}
\hline \multirow{2}{*}{ Naturality } & \multicolumn{2}{|c|}{ Urban } & \multicolumn{2}{|c|}{ Rural } \\
\hline & $\mathbf{N}$ & $\%$ & $\mathbf{N}$ & $\%$ \\
\hline Manaus & - & - & 3 & 8.11 \\
\hline Headquarters of Barcelos & 28 & 53.85 & 14 & 37.54 \\
\hline Santa Isabel do Rio Negro & 1 & 1.92 & 1 & 2.70 \\
\hline São Gabriel da Cachoeira & 1 & 1.92 & 3 & 8.11 \\
\hline Novo Airão & - & - & 1 & 2.70 \\
\hline Amazonas river & 4 & 7.69 & - & - \\
\hline Solimões river & 1 & 1.92 & - & - \\
\hline Purus river & 1 & 1.92 & - & - \\
\hline Demeni river & 2 & 3.85 & 2 & 5.41 \\
\hline Aracá river & 1 & 1.92 & - & - \\
\hline Quiunin river & 1 & 1.92 & - & - \\
\hline Farís river & 1 & 1.92 & - & - \\
\hline Padauarí river & 1 & 1.92 & - & - \\
\hline Anapaxí river & 1 & 1.92 & - & - \\
\hline Community Daracuá & 1 & 1.92 & - & - \\
\hline Community Carvoeiro & 1 & 1.92 & - & - \\
\hline Community Ponta da Terra & - & - & 3 & 8.11 \\
\hline Community Céu Aberto & - & - & 3 & 8.11 \\
\hline Community Pedro II & 1 & 1.92 & - & - \\
\hline Community Paranã do Berurí & 1 & 1.92 & - & - \\
\hline Community São Luís do Rio Negro & 1 & 1.92 & - & - \\
\hline Community Ilha de São Luís & - & - & 1 & 2.70 \\
\hline Community Canutamã & 1 & 1.92 & - & - \\
\hline Community Lago do Jacaré & 1 & 1.92 & - & - \\
\hline Community Baturité & 1 & 1.92 & - & - \\
\hline Community Igarapé Piaba & 1 & 1.92 & - & - \\
\hline Community Quajará & - & - & 1 & 2.70 \\
\hline Community Curarí & - & - & 1 & 2.70 \\
\hline Commmunity Anatí & - & - & 1 & 2.70 \\
\hline Community Atauaí & - & - & 1 & 2.70 \\
\hline Community Airanã & - & - & 1 & 2.70 \\
\hline Community Jaqueira & - & - & 1 & 2.70 \\
\hline Total & 52 & 100 & 37 & 100 \\
\hline
\end{tabular}


The representation of age and civil status was represented in Figures 2 and 3 respectively, in which in urban areas the highest percentage was of fishermen aged over 60 years.

The representation of the educational level, family income and economic activities performance of the "piabeiros" comparing the urban and rural areas of the municipality of Barcelos was showed in Figure 4, 5 and 6

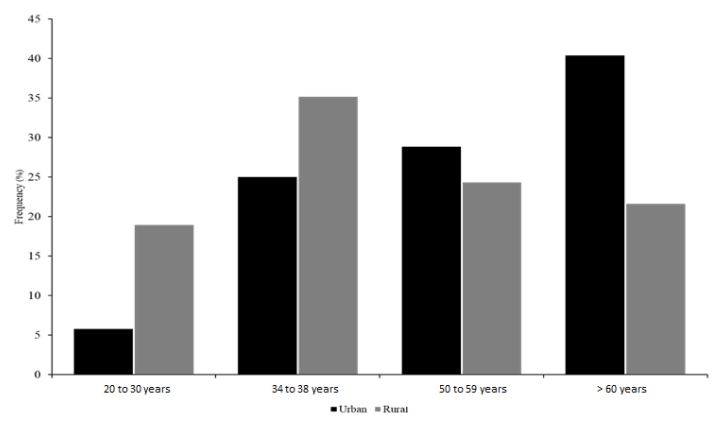

Figure 2. Representation of the age groups of the "piabeiros" of the urban and rural areas of the Municipality of Barcelos, Amazonas, Brazil.

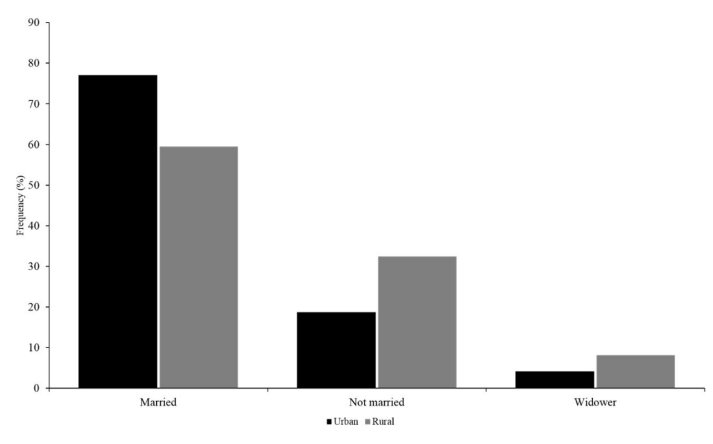

Figure 3. Representation of the civil status of the "piabeiros" of the urban and rural areas of the Municipality of Barcelos, Amazonas, Brazil.

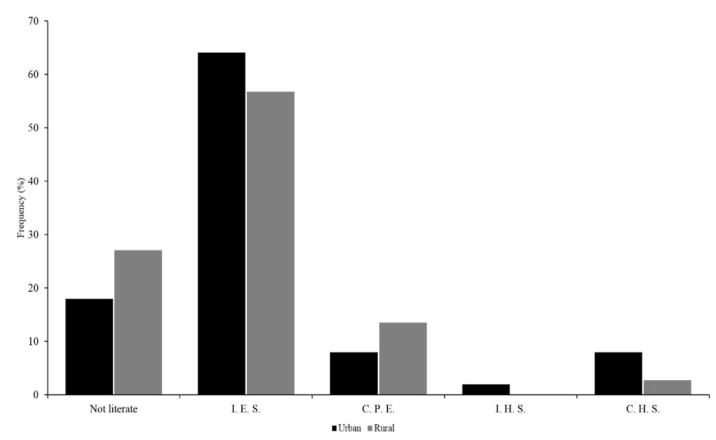

Figure 4. Representation of the educational level of the "piabeiros" of the urban and rural areas of the Municipality of Barcelos, Amazonas, Brazil. Not literate; I. E. S.= Incomplete Elementary School; C. P. E= Complete Primary Education; I. H. S.= Incomplete High School; C. H. S.= Complete High School. respectively. The representation of the ornamental fishing seasons, the main families of ornamental fish caught and marketed and fishing environments according to the "piabeiros" comparing the urban and rural areas of the municipality of Barcelos was showed in Figure 7, 8 and 9 respectively. The representation of fishing equipment used was represented in Table 4, in which the rapiché and the cacuri were the instruments most used by the "piabeiros"

The associativism representation and the main problems related to ornamental fishing according to the "piabeiros" comparing the urban and rural areas of the Municipality of Barcelos was showed in Table 5 and 6 respectively, .

Table 3. Representation of the genus of the "piabeiros" of urban and rural areas in the Municipality of Barcelos, Amazonas, Brazil.

\begin{tabular}{ccc}
\hline \multirow{2}{*}{ Genus } & \multicolumn{2}{c}{ Locations } \\
\cline { 2 - 3 } & Urban (\%) & Rural (\%) \\
\hline Male & 74.51 & 81.08 \\
Female & 24.49 & 18.92 \\
\hline
\end{tabular}

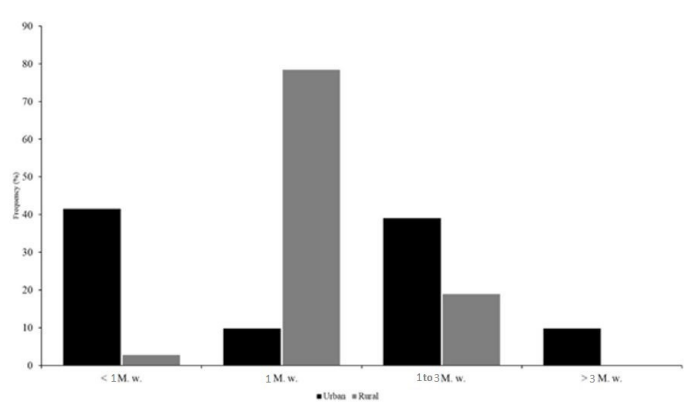

Figure 5. Representation of the family income of the "piabeiros" of the urban and rural areas of the Municipality of Barcelos, Amazonas, Brazil. $<1 \mathrm{M}$. W.= Less than a minimum wage; $1 \mathrm{M}$. W.= Equivalent to a minimum wage; 1 to $3 \mathrm{M}$. W.= Equivalent of one to three minimum wages; $>3 \mathrm{M}$. W.= Equivalent to more than three minimum wages.

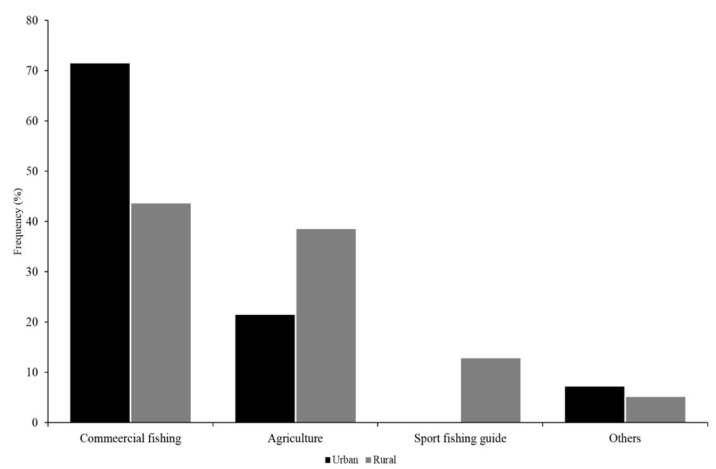

Figure 6. Representation of the economic activities performed by the "piabeiros" of the urban and rural areas of the Municipality of Barcelos, Amazonas, Brazil. 


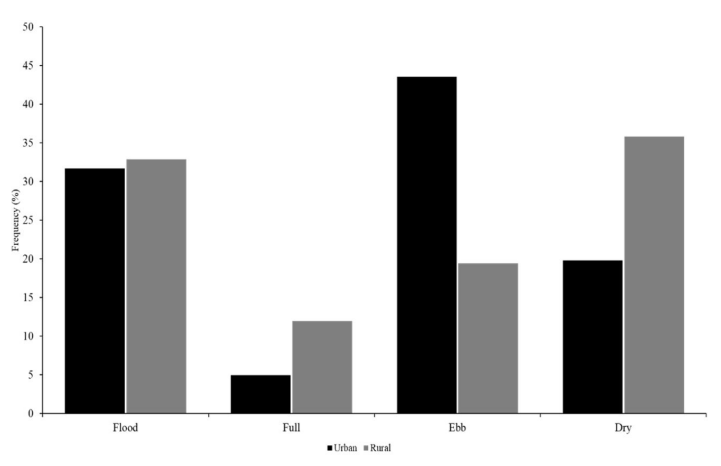

Figure 7. Representation of the ornamental fishing seasons according to the "piabeiros" of the urban and rural areas of the Municipality of Barcelos, Amazonas, Brazil.

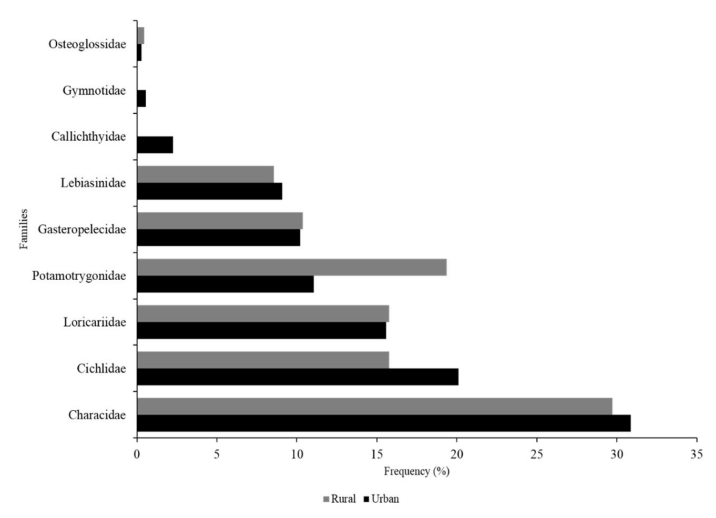

Figure 8. Representation of the main families of ornamental fish caught and marketed according to the "piabeiros" of urban and rural areas in the Municipality of Barcelos, Amazonas, Brazil.

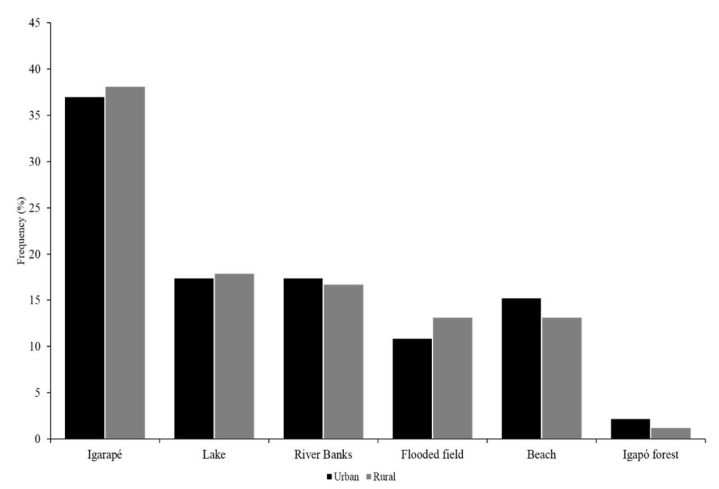

Figure 9. Representation of the fishing environments according to the "piabeiros" of urban and rural areas in the municipality of Barcelos, Amazonas, Brazil.

\section{Discussion}

In relation to interviewees frequency in the communities, larger frequency was observed in the headquarters of the municipal district of Barcelos (Table 1), corresponding a total of $58.43 \%$. For other side had communities that presented
Table 4. Representation of the fishing equipment used by the "piabeiros" of urban and rural areas in ornamental fishery in the municipality of Barcelos, Amazonas, Brazil.

\begin{tabular}{ccc}
\hline Fishing & \multicolumn{2}{c}{ Locations } \\
\cline { 2 - 3 } equipment & Urban (\%) & Rural (\%) \\
\hline Rapiché & 43.81 & 41.89 \\
Puçá & 21.90 & 20.27 \\
Cacuri & 29.52 & 35.14 \\
Talha & 1.90 & 2.70 \\
Zagaia & 2.86 & 0.00 \\
\hline
\end{tabular}

Table 5. Representation of Associativism among the "piabeiros" of urban and rural areas in the municipality of Barcelos, Amazonas, Brazil.

\begin{tabular}{ccc}
\hline \multirow{2}{*}{ Associativism } & \multicolumn{2}{c}{ Locations } \\
\cline { 2 - 3 } & Urban (\%) & Rural (\%) \\
\hline Fishing colony Z33 & 56.00 & 30.30 \\
Association Ornapesca & 2.00 & 3.03 \\
Farmer's union of Barcelos & 0.00 & 3.03 \\
Not associated & 42.00 & 63.64 \\
\hline
\end{tabular}

Table 6. Representation of the main problems related to ornamental fishing according to the "piabeiros" of urban and rural areas in the municipality of Barcelos, Amazonas, Brazil.

\begin{tabular}{ccc}
\hline \multirow{2}{*}{$\begin{array}{c}\text { Active ornamental } \\
\text { fisherman }\end{array}$} & \multicolumn{2}{c}{ Locations } \\
\cline { 2 - 3 } & Urban (\%) & Rural (\%) \\
\hline Yes & 37.50 & 63.89 \\
No & 62.50 & 36.11 \\
\hline
\end{tabular}

smaller number of interviews such as the community of Jaqueira (2.25\%). Although there were efforts to reach the communities of Alalaó and Maquí, there were not possibilities of success the field activities happen in the period of inundation of the rivers. Thus there were some "igarapés" that still met with low level of water. These difficulties in the area were also pointed for Leme and Begossi (2013) and also for Ferreira et al. (2017).

The comparative frequency among the interviewees showed that $58.43 \%$ of the fishermen of ornamental fish are living in urban area, while $41.57 \%$ still live in the rural area. In spite of that it looks similarity, we can observe is a dispersion of those along the communities, giving larger prominence the communities of Ponta da Pedra and Daracuá that still active stay in the ornamental fishing. That observation was also registered by Sobreiro (2016) and Ferreira et al. (2017) during investigations on the social and economic profile in the community of Daracuá, demonstrating like present work a community's importance for the ornamental fishing in the area.

It was also registered a low number of families living at these places. In agreement with the residents that fact is due the decadence of the ornamental fishing in the last years. Starting from 2008, many of the old fishermen had to migrate for the headquarters of the municipal district 
in search of new job opportunities, besides having the access to services of health and closer education, mainly for the fact of many of those residents to possess smaller children of age. The Medio River Negro represents one of the most uninhabited areas of the Amazonian, with low population density, caused by soil characteristics that it is predominant sandy and it doesn't favor the development of the agriculture, and of the rivers that due to the low level of dissolved nutrients and low productivity would excel of the waters. The River Negro is recognized popularly as "river of the hunger." Those crucial factors act as limiting for the fixation of the population (Leme and Begossi, 2013).

Studies by Silva $(2007,2011)$ tell a historical migration of rural communities starting from 1980 towards the urban centers of the area of Medio River Negro, mainly the headquarters of Barcelos and Santa Isabel do Rio Negro. That migratory process happened due to need of search of better jobs, and access to education services and health. Thus many of those families maintained contact with their native communities for several reasons like relationships to the accomplishment of activities as the fishing, cultivation of having cleared and collection of fruits of the forest as the chestnut of Brazil.

We can notice that the practice of residences alternation accomplished by riverine communities from Medio River Negro is not something new, and it is happening to many years under influence of the dynamics of the environmental (readiness of natural resources) and economical (offer of jobs and income) social (access to services of health and education, marriages, school vacations, local conflicts, etc.) (Barra et al., 2013).

Most of the interviewees piabeiros was of the masculine gender, so much the residents in the urban (74.51\%) area as the one of the rural $(81.08 \%)$ areas (Table 3$)$. Low representativeness of the women's action was observed in the ornamental fishing. In spite of that, it is observed that the woman has an expressive participation because carries out the work in an equalitarian way to the men. Scenery different to the that is found in other fishing modalities in Brazil and in the Amazonian where happens the division of gender of the work (Fonseca et al., 2016; Palheta et al., 2016). A lot of times the woman doesn't participate directly of the activities, being that exclusive to the men and the women fits the children's cares and the accomplishment of the daily domestic services (Santana, 2014).

Studies conducted by Carvalho Júnior et al. (2009), Souza and Mendonça (2009) and Rossoni et al. (2014) related the ornamental fishing practiced in other areas of the Amazonia, it has been demonstrating the women's smaller participation or inexistences of those in the activity, with great predominance male. We can mention as example the ornamental fishing in the area of the Medio River Xingu (Pará) (N=60 men), the ornamental fishing in the Reservations of Maintainable Development area Piagaçu-Purus (RMD-PP) in the bass river Purus (Amazon) $(\mathrm{N}=15$ men) and the ornamental fishing of the area of Tefé (Amazon), where the works describe the male predominance.
Analyzing the women's participation in the sea/continental fishing in agreement with data of MPA (Brasil, 2010), it is observed that they represented $40.85 \%(348,553)$ of the Brazilian fishermen registered in the period of 2008-2009, being the northeast area the one that presents equalitarian dimension among genders (46.3\% women and 53.7\% of men). In the state of Amazon the women represented $40.0 \%$ of the fishermen for this period.

In relation to age group a percentage was observed high $(40.38 \%)$ in the urban area of piabeiros with superior age to 60 years. On the other hand the piabeiros of the rural area presented percentage of $35.14 \%$ among the fishermen with age from 34 to 38 years of age (Figure 2). We can notice that a tendency of little renewal of proceeding piabeiros exists in the urban area because the same ones tend to migrate for another commercial activity. On the other hand, the perception of renewal of the piabeiros exists in the rural area, caused due to lack of commercial opportunity. It was also observed that in the rural area the largest group of piabeiros is in the one of age among 34 to 48 years of age.

In agreement with the studies driven by Ferreira et al. (2017) the average of age of fishermen of ornamental fish was of 45 years, with variation from 35 to 71 years. In the present study the average of piabeiros age in the urban area was of 53.72 varying from 24 to 82 years. Already in the urban area the varying was of 47.91 (from 21 to 76 years of age). Same result observed in relation to the predominance found with the resident piabeiros in the rural area, should have the influence of this division (urban and rural), because in that study there was a low number sample that was reiterated by the authors (Ferreira et al., 2017).

The averages of ages of the piabeiros of both study areas were above the medium distribution of the age groups of the national professional fishermen that it is among 30 to 39 years, representing $26.6 \%(221,804)$ of the total (Brasil, 2010). The results demonstrate that the ornamental fishing in Medio River Negro is composed by older fishermen with ages above 40 years.

It is noticed that most of the piabeiros in the rural areas $(37.54 \%)$ as in the urban areas $(53.85 \%)$ they are natural from Barcelos. To the whole they were mentioned in the interviews 32 different birthplaces (Table 2). It is practical common observed along the interviews that the piabeiros portrays their naturalness as being the rivers or the communities. Part of this characteristic is due the communities' distances in relation to the urban areas, especially caused by the geographical isolation of the area and the great amount of bodies of waters that difficulty the access to the urban centers.

Most of interviewees declared married marital status (Figure 3). In the Amazonian the ornamental fishing is developed by riverine families through job of formed work of groups, being is one of the main local economic activities, alternative for obtaining pays and middle of sustenance (Moreau and Coomes, 2008; Carvalho Júnior et al., 2009).

The study of Prang (2001) through an analysis of the ornamental fishing accomplished in the basin of Medio 
River Negro describes the participation of about 10 thousand families in the capture practices and transport of ornamental fish. Study made by Souza and Mendonça (2009) it also described the participation in the ornamental fishing practiced in the area of Tefé, with $87.5 \%$ of the fishermen of ornamental fish in marital status married, with families usually constituted by six people. Thus 35 families were identified as dependents of the fishing and of the I trade ornamental in the area.

The education level presented by the piabeiros was considered low with incomplete fundamental teaching or illiterate (Figure 4). Study conducted by Alencar and Maia (2011) when analyzing the distribution of the Brazilian fishermen for education in relationship the areas of the country, noticed that most of the fishermen just possesses the incomplete fundamental teaching, and the North area $82.8 \%$ of the fishermen with that profile. For Lima et al. (2012), the low education level presented by fishermen of the North area links them still more the fishing, because the no qualification disables that those get job in other economic activities with better remunerations.

This characterization is more evident when the family income of the piabeiros is analyzed. It can be observed that these appear in the smallest strip of income (less than a minimum wage) (Figure 5). Part of the piabeiros from rural area declared to have a family income around a minimum wage (78.38\%) or even minor than that value, as mentioned by the piabeiros from urban area (41.46\%). Being the larger values to three minimum wage more concentrated by piabeiros of the urban $(39.02 \%)$ area, possibly due to the presence of piabeiros "bosses", being responsible for the purchase and sale of the ornamental fish in Barcelos and the supply to the companies of aquarismo of Manaus (Prang, 2001).

For Silva (2007), besides the ornamental fishing, the incomes of many families of the area of the Medio River Negro are composed by social benefits of the Federal Government. According to the data of socio-environmental profile of Barcelos accomplished in partnership by the Federation of Negro River (FOIRN) Indigenous Organizations, Indigenous Association of Barcelos (ASIBA) and the Instituto Socio-environmental (ISA) accomplished in the period from 2009 to $2010,55.54 \%$ of the residents of Barcelos possess fixed income and $62.22 \%$ are employed, where the public employees represent $28.15 \%$ of that total one. Those works also describe that $48.82 \%$ of the families of the municipal district receive some type of financial aid of the Federal Government (Barra et al., 2013).

In the present study most of the interviewees informed to have the ornamental fishing as the main source of income $(61.11 \%)$. However it is noticed that that no longer it is the main source for some $(38.89 \%)$, mainly for the resident piabeiros in the headquarters of Barcelos, where $57.14 \%$ not declared more to depend on the activity to survive. Opposite scenery to this of the urban area is described by the piabeiros of the rural areas, where $78.38 \%$ affirmed to have the ornamental fishing as main middle of obtaining of income.
Many piabeiros end up carrying out other economic activities as form of complementing family income, being those accomplished in the period of "defeso" of cardinal Paracheirodon axelroldi among the months of May to July (IBAMA, Law n 28/1992) (Brasil, 1992). The main economic activities were the eatable fishing of fish, the agriculture (coivara) and guides of the sporting fishing. Many of these carry out occasional activities, as salesperson of fish, aid of bricklayer, craft, chambermaid and cook of boat hotel (Figure 6). According study by Silva and Begossi (2013) the activities as the fishing, the agriculture, the craft and the forest extractives are the main economic activities in communities' of the area of the Medio River Negro.

The fish eatable commercial fishing was the activity that most of the fishermen said to carry out in periods of exports of the ornamental fishing. Among the piabeiros of the urban area, this activity represented $71.43 \%$, while for the fishermen of the rural area this activity represented $43.59 \%$. In the study of Inomata and Freitas (2015), it was described that the fishing activities represent the main source of income and generation of jobs of the primary section, and the fact of the craft fishing not to demand the qualified work, does with that many fishermen choose these activity. The study of Sobreiro (2016) showed a tendency of changes of activity of the ornamental fishing for other linked activities to the fishing section in 2011, with migration of fishermen of the urban and rural area for the eatable commercial fishing of fish.

This fact can be related with the scenery found in the present study, where the interviewees' largest portion declared preference in working in the eatable fishing instead of the sporting fishing. Even the sporting fishing tends expressive growth in the area getting to move US\$ 5 million per year, the equivalent to $10.0 \%$ of GDP of Barcelos (Barroco and Freitas, 2014). Many fishermen from urban area answered that don't identify with the sporting fishing, mainly due to the way of this work is developed, and that activity demands that the fishermen work long hours a day, besides the need of more formal communication with the tourists. That fact was also described in study by Ferreira et al. (2017), where the craft fishermen of ornamental fish of Barcelos complain of the work conditions that are exposed in the sporting fishing in the area. The reports describe that these are not treated with respects by the tourists and forced to work in schedules of larger solar incidence.

The fish eatable commercial fishing was the activity that most of the fishermen said to carry out in periods that contain the exports of the ornamental fishing. Among the piabeiros of the urban area, this activity represented $71.43 \%$, while for the fishermen of the rural area this activity represented $43.59 \%$. In the study of Inomata and Freitas (2015), it was described that the fishing activities represent the main source of income and generation of jobs of the primary section, and the fact of the craft fishing not to demand qualification. The study of Sobreiro (2016) showed a tendency of changes of activity of the ornamental fishing for other linked activities to the fishing section in 
2011, with migration of fishermen of the urban and rural area for the eatable commercial fishing of fish.

The participation in the sporting fishing was mentioned by the fishermen from rural area $(12.82 \%)$ that carry out that activity in the fishing season that corresponds to the period from October to March (period of low water level). In this period those fishermen are contracted mainly for local ecological knowledge, that helps in the choice of best local of fishing of the tucunaré (Cichla spp.) main species of that activity (Barroco and Freitas, 2014). Besides the sporting fishing, the fishermen of the rural area work in the agriculture $(12.82 \%)$ with cassava cultivation in coivara. These fishermen practice the ornamental fishing only during part of the year. In the period in that the exports of the ornamental fishing are closed or the financial incomes with activity are very low when the agriculture is intensified (Chao and Prang, 1997).

The coivara agriculture is had as one of the most important activities for the families from the Negro River (Barra et al., 2013). The "field" is described as the system of earth use by riverine populations with predominance of the cultivation planting of annual species (Fraxe et al., 2009), where the agriculture of coivara is based in the cut and it burns of the forest vegetation for the incorporation of the present nutrients in the ashes to the soil, guaranteeing like this the success of the cultivation (Peroni, 2013).

\section{Characterization of the ornamental fishing of Barcelos}

The ornamental fishing in the basin of the Medio River Negro suffer influence direct of the dynamics of the waters cycle of the Negro River (flood pulse), being to criterion of the fishermen the choice of the best time for the practice of the activity. For the fisherman from the urban area the best is the ebb period and for the rural area fishermen the drought. These are the factors that determine the beginning of the activity (Figure 7). The variation of the waters in Negro River is one of the main characteristics of that tributary, that depending on the annual seasonality and of the place it can vary from 10 to 12 meters and those variations of the level of Negro waters form new placves as lakes, beaches, flooded fields and igapó forests, that serve as shelters, reproduction places and feeding for the aquatic communities (Sioli, 1985; Zeidemann, 2001).

According to data of the Geological Service of Brazil (CPRM, 2017) the seasonal periods of the Negro River understand the following phases: inundation (from December to May), flood (from May to July), ebb tide (from July the other) and drought (from October to November). For the piabeiros of the urban area the best time for the capture of ornamental fish if gives at that time of ebb tide (43.56\%) and inundation (31.68\%).

For the piabeiros of the rural areas the best period would be at that time of drought (35.82\%) and in the inundation $(32.84 \%)$. However for both, the dry period is described as a time of difficult displacement due to the banks of sands and existent geographical isolation in some places.
According study by Siqueira-Souza et al. (2006), these periods are considered as the best time for the capture of ornamental fish in the area (ebb tide and drought), because in time of full of the rivers in the area the fish end if dispersing to the igapó forests the food search and reproduction, hindering like this the capture for the fishermen.

The Black river show a rich diversity of species of fish, approximately 450 species, and many are endemic of the basin and still ignored, not being classified / described. In this vast number of species, some are used for ornamental ends (Loebens et al., 2016). With base in the reports and descriptions accomplished by the piabeiros during the interviews, it was possible to accomplish the identification of the main families of ornamental fish marketed in the area, being to the whole ten families: Characidae, Lebiasinidae, Gasteropelecidae, Cichlidae, Anostomidae, Oesteoglossiformes, Loricarridae, Potamotrygoniade, Callichthyidae and Gymnotidae (Figure 8).

The piabeiros of the urban area mentioned a larger amount of families than the residents of the rural area. This fact happens possibly in reason of the locomotion capacity of the fishermen to their fishing (fishing areas) ones that are a lot of times located in more distant areas of the headquarters of the Municipal district of Barcelos, and also that the same ones count with a structure of larger fishing than the residents in the rural area, as well as the costing on the part of the middlemen (bosses) of ornamental fish of the area for accomplishment of their fishing campaigns, counting with support of embarkations of medium load motorized. On the other hand, the piabeiros of the rural area end up practicing the fishing only in close areas their places, where a lot of times the atmospheres favor the capture of a smaller diversity of species of ornamental fish.

We can note that exist piabeiros experts in capture species from specify families such as Characidae, Cichlidae, Loricarridae and Potamotrygonidae. That fact can be observed in the urban area and in some communities as Daracuá. When asked on the capture specificity, the main explanation was the value commercial attachment of the species that compose these groups, that compensating the expenses and generating a satisfactory markup to the fisherman. The selectivity in the ornamental fishing can also be observed in other areas of the Amazonian, as in the case of Medio River Xingu (Pará State) that in spite of existing about 200 species of ornamental fish in the area, the fishing ends if concentrating in only 10 species in reason of their high market values (Carvalho Júnior et al., 2009).

In the present study it is possible infer that the ornamental fishing is concentrated mainly in the family's Characidae, Lebiasinidae, Gasteropelecidae, Cichlidae, Loricariidae and Potamotrygonidae. The main representatives of these families were the cardinal Paracheirodon axelrodi, rodostomos Hemigrammus bleheri, butterfly Carnegiella spp., acará disco Symphysodon discus, bodós (Loricarridae) and stingrays (Potamotrygonidae) respectively, corroborating the data described by Chao and Prang (1997), Anjos et al. (2009), Sobreiro (2016) and Ferreira et al. (2017). 
For the capture of those species the main used equipment's are the rapiché, the cacuri, puçá, cuts and the zagaia (Table 4), as well as having described for of Barra et al. (2012), Sobreiro (2016) and Ferreira et al. (2017) that studied the ornamental fishing in the area.

The rapiché was more frequently cited by the fishermen of the urban area $(43.81 \%)$ and rural $(41.89 \%)$, it is an accessory made by piabeiros with a flexible wood known locally by "ripeira", where two sticks and stitched a nylon mesh, giving the appearance of basket (Barra et al., 2012; Ferreira et al., 2017). According to the piabeiros, it is a very useful tool for catching "piabas" in streams and in areas free of vegetation or shrubs, and its use is related to the efficiency that this device demonstrates at the time of fishing.

The cacuri, as well as the rapiché, was also widely used. This was cited by $29,52.0 \%$ of the urban piabeiros and $35.14 \%$ of the rural area. However different from the rapiché, this equipment is constructed with a wooden arch with nylon fabrics sewn on the sides, as well as a heavier wood attached to the bottom, being used as a temporary trap in environments of difficult access such as flooded fields, with the use of baits to attract fish (Barra et al., 2012; Ferreira et al., 2017).

The puçá, like the rapiché and the cacuri, is constructed with nylon canvas by the piabeiros in an artisan way, with the purpose of catching the ornamental fish individually or in smaller quantities (Barra et al., 2012; Ferreira et al., 2017). Being very used in the handling or counting of fish like stingrays and acará disco (Symphysodon discus) during the transport.

The hoist according to the information of the piabeiros is a tool used for the lifting of heavy loads, which has been adapted for ornamental fishing, mainly for the capture of bodhi, since they are fish residing in the submerged trunks on the banks of the lakes and in the bottom of the igarapés.

The zagaia is a wooden rod approximately 2 meters long with a trident style steel spear at the end (Barra et al., 2012), used to catch stingrays during breeding season, where the fisherman after a throw on the edges of the fish disc, holds it and places it with the belly up in the bottom of the canoe, forcing the delivery with release of the cubs by the female.

When asked about this practice of capture and not the collection of nature, the piabeiros expose that such a procedure is often occasional, but that greatly facilitates the capture of stingrays in the natural environment, thus gaining more time and achieving an amount even greater than usual, because the individuals obtained through this practice are within the maximum size limit that the market demands, which is $30 \mathrm{~cm}$ wide for the species $P$. motoro, P. schroederi, and $14 \mathrm{~cm}$ for $P$. cf. histrix (Brasil, 2005).

Ornamental fishing occurs in several environments according to the local seasonality, in this study the igarapés were the most preferred environments for those interviewed with $36.96 \%$ by the piabeiros of the urban area and $38.10 \%$ of the rural área (Figure 9). In addition to the igarapé other environments were cited as Lakes, river banks, flooded fields, beaches and igapó forest.
It is noted that the choice of fishing sites is based on the empirical knowledge (cognitive capital) of the fishermen on the behavior of the ornamental fish species of the region, such knowledge is constructed with the years of work practice in the activity, which enables the fisherman to choose the best equipment, technique, season, and place to fish with better efficiency the desired species (Witkoski et al., 2009; Silvano, 2013).

\section{The ornamental fishing scenario in Barcelos}

The fishing colony Z33 in the city of Barcelos is the main institution in which the fishermen are associated, followed by the Fishermen and Fishermen's Cooperative of Ornamental Fish of the Middle and Upper River Negro (ORNAPESCA), however it is noted that there are fishermen who does not have any type of link with the institutions of the local fishing sector (Table 5).

Access to closed insurance is one of the main reasons for the association in the category of fishermen of both zones with the Z33 Fishing Colony, as a fundamental aid to support the family in the period of prohibition of fishing of some species of commercial importance in the region, this fact is also exposed in the study by Ferreira et al., 2017, where part of the fishermen of ornamental fish demonstrate not to expect contributions their professional lives coming from the fishing colony.

Among the piabeiros in the rural areas, most reported not being associated with any institution in the sector (63.64\%), with only $30,30.0 \%$ associated with Z33 Fishing Colony, and $3.03 \%$ with Ornapesca, others $3.03 \%$ to the Farmers' Union of Barcelos. Logistical and bureaucratic issues were the main reasons why many fishermen in this region were not associated with the sector institutions.

According to Sobreiro (2016), as of the year 2000, ornamental fishery in the region of the Medio River Negro began to show signs of decline, leading to the mobilization of national and regional institutions in order to promote the activity, the actions of this project resulted in the creation of Cooperative of Fishermen and Fishermen of Ornamental Fish of the Medio and Upper Rio Negro (ORNAPESCA) in 2008, where new structures and technology were introduced to improve the sanitary quality of ornamental fish in the region.

Through an interview with president of Ornapesca in december 2016 in the city of Barcelos, it was reported that the initial idea of this development project was to improve the working conditions, storage, health quality and values of ornamental fish through However, the actions carried out did not have the expected results due to bureaucratic problems on the part of the government agencies, which made it impossible to provide financial aid to the sector and did not comply with the proposals agreed with the fishermen.

Currently, what is seen in the ornamental fishery is a balance of the number of active fishermen in the municipality, where $48.0 \%$ of the total number of piabeiros 
interviewed were active and $51.19 \%$ said that they did not work on the activity.

However many piabeiros still live in this activity, even in the face of the socioeconomic changes that ornamental fishing has faced in the last decade, influenced by the reduction of the export volume of fish of origin of the Negro river basin and problems related to the organization of the productive chain, besides the lack of attention to the sector by the public power (Sobreiro, 2016). This is more evident when it is observed that in the rural area the number of assets $63.89 \%$ is higher than in the urban area $(37.50 \%)$ where the number of inactive is higher $(62.50 \%)$.

According to Ferreira et al. (2017) fishermen interviewed in their study reported that ornamental fishing in the region is in decline, and that many of these fishermen only began to feel the effect of such changes between the years 2007 to 2010. This period coincides with the closure of the largest buyer of ornamental fish in the region, the company Turkys Aquarium, which owned $51.2 \%$ of the ornamental fish market in the State of Amazonas (Sobreiro, 2016). This event may have reflected directly on the local economy, where the main current related problems are related to the absence of ornamental fish buyers, the reduction of sales, as well as the low financial profit that activity currently provides (Table 6).

Chao and Prang (1997) in their study already alerted to the emergence of problems related to regulatory insufficiencies of the activity, unequal international competition, reproduction and marketing of species targeted in captivity by importing countries, and may influence social, economic and environmental impacts. We note the occurrence of other problems related to the production chain in addition to those cited by the authors, such as delay in the payment of production by the middlemen and health issues due to the average age of the piabeiros that most present, where many claim not to be more able to work in the activity, since it has an arduous work order that requires certain physical aptitude and perfect vision for locating and identifying many species.

In view of the results of the present study it is well known that the dynamics of the ornamental fishery seems to have undergone changes in a short time, directly affecting the category of artisanal fishermen of ornamental fish, causing many to adopt other economic activities such as commercial fishing of edible fish. This event should be seen with some attention because the migration of fishermen to other activities may increase the dispute over the resource with other fishing modalities in the region, a fact already pointed out by other studies developed in the region.

This study also demonstrates a greater participation of older fishermen and a low age renewal, a fact that indicates the absence of younger fishermen, since the activity scenario is not more attractive for the younger ones, bringing a concern regarding the transmission of the future generations, should this scenario continues.

Regarding the ecological aspects, there seems to have been no change over the years in relation to the composition of the main groups (families) of fish traded in Barcelos, as well as in the artisanal techniques of capture. What has intensified are the problems related to the local productive chain, which lacks the structure and technology to improve the quality of the animals coming from the Middle Rio Negro basin, in addition to the public attention to the activity, since the ornamental fishery has already been treated as one of the most important local economic activities, contributing financially and socially to the State of Amazonas.

\section{Acknowledgements}

The present study was supported by the Foundation for Research Support of the State of Amazonas (FAPEAM), through Project Propesca - Rio Negro (public notice no. 010/14); Federal Institute of Education, Science and Technology of Amazonas - IFAM.

\section{References}

ALENCAR, C.A.G. and MAIA, L.P., 2011. Socioeconomic profile of the Brazilian fishermen. Arquivos de Ciência do Mar, vol. 44 , no. 3 , pp. 12-19.

ANJOS, H.D.B., AMORIM, R.M.S., SIQUEIRA, J.A. and ANJOS, C.R., 2009. Exportação de peixes ornamentais do Estado do Amazonas, Bacia Amazônica, Brasil. Boletim do Instituto de Pesca, vol. 35, no. 2, pp. 259-274.

BARRA, C.S., DIAS, C.J. and CARVALHEIRO, K., 2012. Manejo Pesqueiro no Médio Rio Negro: Barcelos. São Paulo: Instituto Socioambiental. Séries Pescarias no Rio Negro, vol. 2, 34 p.

BARRA, C.S., DIAS, C., CAMPOS, C.S.S., SOARES, C.S., FILHO, E.S.P. and PINHEIRO, F.G., 2013. Barcelos Indigena e Ribeirinha: um perfil socioambiental. São Paulo: Instituto Socioambiental, $156 \mathrm{p}$.

BARROCO, L.S.A. and FREITAS, C.E.C., 2014. A pesca esportiva na Amazônia: implicações para a sustentabilidade dos estoques pesqueiros e da atividade. Revista Scientia Amazonia, vol. 3, no. 2, pp. 93-99.

BATISTA, V.S. and LIMA, L.G., 2010. Search of traditional bio-ecological knowlwdge useful for fisheries co-management: the case of jaraquis Semaprochilodus spp. (Characiformes, Prochilodontidae) in Central Amazon, Brazil. Journal of Ethnobiology and Ethnomedicine, no. 15, pp. 6-15. http://dx.doi. org/10.1186/1746-4269-6-15.

BEGOSSI, A., SALIVONCHYK, S., LOPES, P.F.M. and SILVANO, R.A.M., 2016. Fishers' knowledge on the coast of Brazil. Journal of Ethnobiology and Ethnomedicine, vol. 12, no. 1, pp. 12-20. http://dx.doi.org/10.1186/s13002-016-0091-1. PMid:27245047.

BRASIL. Instituto Brasileiro do Meio Ambiente e dos Recursos Naturais Renováveis - IBAMA, 1992. Portaria $n^{\circ} 28,10$ de março de 1992. Normatiza a captura e comercialização de peixes ornamentais do Estado do Amazonas (periodo de defeso do cardinal Paracheirodon axelrodi. Diário Oficial da República Federativa do Brasil, Brasília.

BRASIL. MINISTÉRIO DO MEIO AMBIENTE - MMA, 2005. Instrução normativa $n^{\circ} 27$, de 31 de agosto de 2005. Trata das recomendações decorrentes das reuniões técnicas realizadas pelo 
Instituto Brasileiro do Meio Ambiente e dos Recursos Naturais e Renováveis-IBAMA, sobre ordenamento do uso de raias de água continental, família Potamotrygonidae, para fins ornamentais e de aquariofilia. Diário Oficial da República Federativa do Brasil, Brasília, 6 de setembro.

BRASIL. MINISTÉRIO DA PESCA E AQUICULTURA MPA. 2010. Boletim estatístico da pesca e aquicultura. Brasília: Ministério da Pesca e Aquicultura.

CARVALHO-JÚNIOR, J.R., CARVALHO, N.A.S.S., NUNES, J.L.G., CAMÕES, A., BEZERRA, M.F.C., SANTANA, A.R. and NAKAYAMA, L., 2009. Sobre a pesca de peixes ornamentais por comunidades do rio Xingu, Pará- Brasil: relato de caso. Boletim do Instituto de Pesca, vol. 35, no. 3, pp. 521-530.

CHAO, N.L. and PRANG, G., 1997. Project Piaba- towards a sustainable ornamental fishery in the Amazon. Aquarium Sciences and Conservation, no. 1, pp. 105-111.

FERREIRA, V.A.M., RODRIGUES, T.T.E., YAMAMOTO, K.C., FREITAS, C.E.C. and NOGUEIRA, A.J.A., 2017. Caracterização socioeconômica da pesca ornamental no município de Barcelos. Observatório de la Economía Latinoamericana, vol. 3, pp. 1-20.

FONSECA, M., ALVES, F., MACEDO, M.C. and AZEITEIRO, U., 2016. M. O papel das mulheres na pesca artesanal marinha: estudo de uma comunidade pesqueira no município de Rio das Ostras, RJ, Brasil. Revista de Gestão Costeira Integrada, vol. 16, no. 2, pp. 231-241. http://dx.doi.org/10.5894/rgci593.

FRAXE, T.J.P., BRITO, M.A.S., SILVA, S.C.P., ARAUJO, E.M. and OLIVEIRA, L.C., 2009. A vida social das comunidades do lago Manacapuru (AM). In: T.J.P. FRAXE, A.C. WITKOSKI and S.C.P. SILVA. A pesca na Amazônia Central: ecologia, conhecimento tradicional e formas de manejo. Manaus: Editora da Universidade Federal do Amazonas, cap. 2, pp. 45-74.

FREITAS, C.E.C. and RIVAS, A.A.F., 2006. A pesca e os recursos pesqueiros na Amazônia ocidental. Ciência e Cultura, no. 3 , pp. $30-32$.

INOMATA, S.O. and FREITAS, C.E.C., 2015. A pesca comercial no Médio Rio Negro: aspectos econômicos e estrutura operacional. Boletim do Instituto de Pesca, vol. 41, no. 1, pp. 79-87.

INSTITUTO BRASILEIRO DE GEOGRAFIA E ESTATÍSTICA - IBGE, 2017. Censo demográfico: cidades. Rio de Janeiro: IBGE.

LEME, A. and BEGOSSI, A., 2013. Uso e conservação de recursos por ribeirinhos no Médio Rio Negro. In: A. BEGOSSI, org. Ecologia de pescadores da Mata Atlântica e da Amazônia. São Paulo: Editora RIMA, vol. 3, pp. 45-88.

LIMA, M.A.L., DORIA, C.R.C. and FREITAS, C.E.C., 2012. Pescarias artesanais em comunidades ribeirinhas na Amazônia brasileira: perfil socioeconômico, conflitos e cenário da atividade. Ambiente \& Sociedade, vol. 15, no. 2, pp. 73-90. http://dx.doi. org/10.1590/S1414-753X2012000200005.

LOEBENS, S.C., FARIAS, E.U., YAMAMOTO, K.C. and FREITAS, C.E.C., 2016. Diversidade de assembleias de peixes em floresta alagada de águas pretas da Amazônia Central. Revista Scientia Amazonia, vol. 5, no. 1, pp. 37-44.

MACHADO, R., 2001. Life and culture on the Rio Negro, Brazil. In: N.L. CHAO, P. PETRY and G. PRANG. Conservation and management of ornamental fish resouces of the Rio Negro Basin, Amazonia, Brazil. Manaus: Editora da Universidade do Amazonas, pp. 27-36. Project Piaba.
MENDONÇA, M. and CAMARGO, M., 2006. Etnoecologia da produção de peixes ornamentais num sector do médio Rio Solimões, Flona Tefé e Reservas Mamirauá e Amanã - Estado do Amazonas. Revista Uakari, vol. 2, no. 1, pp. 53-61. http:// dx.doi.org/10.31420/uakari.v2i1.15.

MOREAU, M.A. and COOMES, O.T., 2008. Structure and organisation of small- scale freshwater fisheries: aquarium fish collection in western Amazonia. Human Ecology, 36(3): 309-323. https://doi/org/10.1007/s10745-008-9160-y.

OLIVEIRA, A.T., ARAÚJO, M.L.G., LEMOS, J.R.G., SANTOS, M.Q.C., PANTOJA-LIMA, J., ARIDE, P.H.R., TAVARES-DIAS, M. and MARCON, J.L., 2017b. Ecophysiological interactions and water-related physicochemical parameters among freshwater stingrays. Brazilian Journal of Biology $=$ Revista Brasileira de Biologia, vol. 77, no. 3, pp. 616-621. http://dx.doi.org/10.1590/15196984.01816. PMid:27783760

OLIVEIRA, A.T., SANTOS, M.Q.C., ARAUJO, M.L.G., LEMOS, J.R.G., SALES, R.S.A., PANTOJA-LIMA, J., TAVARES-DIAS, M. and MARCON, J.L., 2016. Hematological parameters of three freshwater stingray species (Chondrichthyes: Potamotrygonidae) in the middle Rio Negro, Amazonas state. Biochemical Systematics and Ecology, vol. 69, pp. 33-40. http:// dx.doi.org/10.1016/j.bse.2016.07.002.

OLIVEIRA, A.T., ARAÚJO, M.L.G., PANTOJA-LIMA, J., ARIDE, P.H.R., TAVARES-DIAS, M., BRINN, R.P. and MARCON, J.L., 2017a. Cyrilia sp. (Apicomplexa: Haemogregarinidae) in the Amazonian freshwater stingray Potamotrygon wallacei (cururu stingray) in different hydrological phases of the Rio Negro. Brazilian Journal of Biology $=$ Revista Brasileira de Biologia, vol. 77, no. 2, pp. 413-416. http://dx.doi.org/10.1590/15196984.00416. PMid:27533723.

PALHETA, M.K.S.P., CAÑETE, V.R. and CARDOSO, D.M., 2016. Mulher e mercado: participação e conhecimentos femininos na inserção de novas espécies de pescado no mercado e na dieta alimentar dos pescadores da Resex Mãe Grande em Curuça (PA). Boletim do Museu Paraense Emílio Goeldi. Ciências Humanas, vol. 11, no. 3, pp. 601-619. http://dx.doi.org/10.1590/1981.812 22016000300004

PERONI, N., 2013. Agricultura de pescadores. In: A. BEGOSSI, org. Ecologia de pescadores da Mata Atlântica e da Amazônia. São Paulo: Editora RIMA, vol. 3, pp. 19-46.

PRANG, G., 2001. Aviamento and the ornamental fishery of the Rio Negro, Brazil: implications for sustainable resouce use. In: N.L. CHAO, P.P.G. PRANG, T. SONESCHIEN and M. TLUSTY, org. Conservation and management of Ornamental Fish Resources of the Rio negro basin, Amazonia, Brazil. (Project Piaba). Manaus: Editora da Universidade do Amazonas, pp. 43-67.

RAMOS, F.M., ARAUJO, M.L.G., PRANG, G. and FUJIMOTO, R.Y., 2015. Ornamental fish of economic and biological importance to the Xingu River. Brazilian Journal of Biology $=$ Revista Brasileira de Biologia, vol. 75, no. 3, suppl. 1, pp. 95-98. http:// dx.doi.org/10.1590/1519-6984.02614BM. PMid:26691080.

ROSSONI, F., FERREIRA, E. and ZUANON, J., 2014. Fishery and local ecological knowledge of the discus (Symphysodon aequifasciatus, Pellegrin 1904: Cichlidae) na Reserva de Desenvolvimento Sustentável Piagaçu- Purus, baixo rio Purus, Brasil. Boletim do Museu Emílio Goeldi. Ciências Humanas, vol. 9, no. 1, pp. 109-128.

SANTANA, C.G., 2014. As percepções ambientais de pescadores e marisqueiras acerca da divisão sexual de trabalho de pesca em 
Pirambu/SE. Revista Ambivalência, vol. 2, no. 3, pp. 86-105. http://dx.doi.org/10.21665/2318-3888.v2n3p86-105.

SERVIÇOS GEOLÓGICOS DO BRASIL - CPRM, 2017 [viewed 3 July 2018]. Dados fluviométricos do Rio Negro [online]. Available from: http://www.cprm.gov.br

SILVA, A.L. and BEGOSSI, A., 2013. Uso de recursos por ribeirinhos no médio rio Negro. In: A. BEGOSSI, org. Ecologia de pescadores da Mata Atlântica e da Amazônia. São Paulo: Editora RIMA, pp. 45-96.

SILVA, A.L., 2007. Comida de gente: preferências e tabus alimentares entre os ribeirinhos do Médio rio Negro (Amazonas, Brasil). Revista de Antropologia, vol. 50, no. 1, pp. 125-179. http:// dx.doi.org/10.1590/S0034-77012007000100004.

SILVA, A.L., 2011. Entre tradições e modernidade: conhecimento ecológico local, conflitos de pesca e manejo pesqueiro no rio Negro, Brasil. Boletim do Museu Emílio Goeldi, vol. 6, no. 1, pp. 141-163. http://dx.doi.org/10.1590/S1981-81222011000100009.

SILVANO, R.A.M., 2013. Pesca artesanal e etnoictiologia. In: A. BEGOSSI, org. Ecologia de pescadores da Mata Atlântica e da Amazônia. São Paulo: Editora RIMA, 131-161.
SIOLI, H., 1985. Amazônia: fundamentos de ecologia da maior região deflorestas tropicais. Petrópolis: Editora Vozes Ltda, pp. 15-44.

SIQUEIRA-SOUZA, F.K., BARBOSA, R.P. and FREITAS, C.E.C., 2006. Peixes do Médio Rio Negro: uma abordagem ecológica. Manaus: Editora da Universidade do Amazonas, 44 p.

SOBREIRO, T., 2016. Dinâmica socioecológica e resiliência da pesca ornamental em Barcelos, Rio Negro, Amazonas, Brasil. Sustentabilidade em Debate, vol. 7, no. 2, pp. 118-134. http:// dx.doi.org/10.18472/SustDeb.v7n2.2016.15127.

SOUZA, R.L. and MENDONÇA, M.R., 2009. Caracterização da pesca e dos pescadores de peixes ornamentais da região de Tefé, Amazonas. Revista Uakari, vol. 5, no. 2, pp. 7-17. http:// dx.doi.org/10.31420/uakari.v5i2.61.

WITKOSKI, A.C., BRITO, M.A.S., FRAXE, T.J.P. and SILVA, S.C.P., 2009. Etnoconhecimento e práticas de pesca. In: T.J.P. FRAXE, A.C. WITKOSKI and S.C.P. SILVA. A pesca na Amazônia Central: ecologia, conhecimento tradicional e formas de manejo. Manaus: Editora da Universidade Federal do Amazonas, pp. 113-161.

ZEIDEMANN, V.K., 2001. O rio das Águas Negras. In: D. VARELLA. Florestas do Rio Negro. São Paulo: Editora Schwarcz Ltda, pp. 63-87. 